\title{
The Effect of Marshallian and Jacobian Knowledge Spillovers on Jobs in the Solar, Wind and Energy Efficiency Sector
}

\author{
Luigi Aldieri $^{1, *(\mathbb{D} \text {, Jonas Grafström }}{ }^{2,3}$ and Concetto Paolo Vinci $^{1}$ (D) \\ 1 Department of Economic and Statistical Sciences, University of Salerno, 84084 Fisciano, Italy; cpvinci@unisa.it \\ 2 The Ratio Institute, 10364 Stockholm, Sweden; Jonas.grafstrom@ratio.se \\ 3 Economics Department, Lulea University of Technology, 97187 Luleå, Sweden \\ * Correspondence: laldieri@unisa.it
}

check for

updates

Citation: Aldieri, L.; Grafström, J.; Vinci, C.P. The Effect of Marshallian and Jacobian Knowledge Spillovers on Jobs in the Solar, Wind and Energy Efficiency Sector. Energies 2021, 14, 4269. https://doi.org/10.3390/ en14144269

Academic Editors: Sergio Ulgiati, Marco Casazza, Pedro L. Lomas and Wen-Hsien Tsai

Received: 28 May 2021

Accepted: 13 July 2021

Published: 14 July 2021

Publisher's Note: MDPI stays neutral with regard to jurisdictional claims in published maps and institutional affiliations.

Copyright: (C) 2021 by the authors Licensee MDPI, Basel, Switzerland. This article is an open access article distributed under the terms and conditions of the Creative Commons Attribution (CC BY) license (https:// creativecommons.org/licenses/by/ $4.0 /)$.

\begin{abstract}
The purpose of this paper is to establish if Marshallian and Jacobian knowledge spillovers affect job creation in the green energy sector. Whether these two effects exist is important for the number of jobs created in related fields and jobs pushed away in other sectors. In the analysis, the production efficiency, in terms of jobs and job spillovers, from inventions in solar, wind and energy efficiency, is explored through data envelopment analysis (DEA), based on the Malmquist productivity index, and tobit regression. A panel dataset of American and European firms over the period of 2002-2017 is used. The contribution to the literature is to show the role of the spillovers from the same technology sector (Marshallian externalities), and of the spillovers from more diversified activity (Jacobian externalities). Since previous empirical evidence concerning the innovation effects on the production efficiency is yet weak, the paper attempts to bridge this gap. The empirical findings suggest negative Marshallian externalities, while Jacobian externalities have no statistical impact on the job creation process. The findings are of strategic importance for governments who are developing industrial strategies for renewable energy.
\end{abstract}

Keywords: energy efficiency; data envelopment analysis; knowledge spillovers; patents; job creation

\section{Introduction}

There is an increasing interest in employment effects of the European green energy transition [1-3]. Job development from the green energy sectors has evolved into political priority to decrease unemployment, while at the same time safeguarding a sustainable economic growth path $[4,5]$. A debate on the employment effects of green energy is ongoing-without an answer to-what the net impact of green energy on jobs are [6-13].

While there are plenty of studies that cover the number of direct, indirect and induced jobs from green energy, there is a clear gap when it comes to our understanding on how the advances in green energy technologies creates new jobs in other sectors or reduces them (see e.g., [12,14]). There are, to our knowledge, few empirical studies considering how the knowledge spillover diffusion process affects job-creation in the green energy sector $[15,16]$. Hence, a knowledge gap exists concerning employment spillover effects green energy knowledge spillovers (in this paper solar, wind and fuel efficiency is studied, and henceforth called green energy) [17-21].

Despite high hopes concerning employment creation, the evidence is mixed with for example Aldieri et al. [22] who saw fewer than expected jobs from wind power installations and Dell'Anna [23] who found large positive effects on jobs and the economy from energy efficiency development. This paper is relevant because the technological transition process to renewable energy is an important challenge and opportunity for employment [24]. What is not seen is how renewable energy development affects other sectors, and the unseen might be equally important when judging related job effects.

The purpose of this paper is to establish if Marshallian and Jacobian knowledge spillovers affect job creation in the green energy sector. Whether these two effects exist is 
important to increase the understanding of the number of jobs created in related fields to green energy, and jobs pushed away in other sectors, a question that is far from settled [25]. Two questions are investigated. Firstly, are there Marshallian spillovers from the green energy sector, and have the Marshallian spillovers a negative effect on job creation? Secondly, are there Jacobian spillovers from other energy technology sectors and have they a positive effect on job-creation?

To empirically investigate the two questions a unified framework is used, paying attention to both intra-industry spillovers, Marshallian or specialised spillovers [26-28], interindustry spillovers and Jacobian or diversified spillovers [29]. To evaluate the technological diversity between the firms, a Mahalanobis environmental matrix is employed [29], where solar, wind and fuel efficiency patents are distributed across more classes of technology. A reduced equation is estimated where the efficiency process considers the measurement of efficiency of decision making units with reference to the potential for input-specific increases due to the innovation activity, where the output variable is the ratio between sales and the number of employees [30-34].

The period covered is 2002 to 2017 , capturing the majority period in which global installed capacities of green energy were constructed. Beside the USA, other European countries are considered-United Kingdom, Denmark, Belgium, Germany, Finland, France, Italy, the Netherlands and Sweden. The selection of the firms depend on the matching process between Scoreboard data and patents, so any missing data can be removed [31]. The employment effects of the solar, wind and energy efficiency patents are identified as a combination of negative job destruction effects and positive compensation forces [14-16].

The paper is structured in the following way. Section 2 presents a background literature that consist of works that discuss how technology develops and spill over to other field, job effects of renewable energy and a background about Marshallian and Jacobian spillovers. Section 3 explains the theoretical Framework and Econometric Modelling Strategy. Section 4 describes the data. Section 5 provides the results, while Section 6 discusses the policy implications of the findings. Section 7 reports the concluding remarks and explains the directions for future research.

\section{Background Literature}

Innovation is often fashioned within a technological field, but knowledge spillovers across technologies also occur [35-42]. Previous knowledge spillover studies concerning wind and solar power considered effects on technological change of knowledge flows [43,44]. Assessing inter-technology effects enables us to understand unintended consequences of policy decisions. Policy for the promotion of green energy could create employment and development in related, and less related fields.

Thus, the exploration of the differentiated patterns among countries and sectors in the co-evolution of environmental performances and employment could increase the understanding of employment differences, reflecting the prevalence of complementarity or trade-off effects between employment and environmental performances [44]. Investments in environmental technologies might be at the basis of positive complementarities between employment and environmental performances [45].

A key characteristic of technological change is that innovation builds upon prior existing knowledge and the ability to absorb new knowledge [46-48]. Both the Marshallian and Jacobian theory can be said to handle technological externalities, where advancements and innovations in one firm enhance the productivity of the other firms [49]. The original firm where the innovation occurred does not reap the full benefit, and hence there are externalities. The theoretical foundations of these types of knowledge spillovers have a long history and have been widely utilised [50-52].

Marshallian externalities as a driver of growth are influential $[28,53]$. However, there are critiques against the notion that Marshallian spillovers creates growth in some geographic locations. Innovation will have robust clusters patterns [54], but the distribution of employment from the innovation will not correspond to these clusters. Another insight 
was that innovation and production does not necessarily occur at the same location [30]. Therefore, variety and diversity are important for development, and then geographically close industries, rather than geographical specialisation, stimulate innovation and growth.

Knowledge diffusion is important for economic growth [55-60]. Knowledge flows within and beyond the same technology with a potential to reinforce other knowledge generating processes $[54,55]$. Consequently, gains in an existing technology can be transferred to the same or different technology fields.

According to Nemet [42], the indications of inter-technology knowledge spillovers are broad, if anecdotal. An energy sector example is when jet engines for military aircraft provide the fundamental technology for high efficiency natural gas power plants. General Electric's LM6000 50 MW gas turbine is directly descended from the TF39 high-bypass turbo-fan engine, developed in the 1960s. The wind turbines of today are a product of knowledge from other industries, especially marine, but also aerospace and electronics. For example, knowledge from pipe building, magnet manufacturing and marine propulsion was necessary for the upscaling of wind turbines.

In his seminal work, Griliches [55] identified two types of spillovers. In a pure knowledge spillover, i.e., where the spillover is not incorporated into tradable goods, the relevant knowledge is instead transferred between firms devoid of the knowledge recipient directly paying the knowledge producer. There are also rent spillovers, which occur when an improvement in physical productivity derived from a technological innovation in a product, does not produce a price adjustment of the same magnitude.

Pure and rent knowledge spillovers can spread in two ways [29]. The first builds on a Jacob-type externality frame where one actor's knowledge production is a beneficial input for the knowledge production function of other heterogeneous actors on all development levels. Jacob-type knowledge spillovers have no or little requirement of previous research. The second way, a Marshall-type externality is where knowledge only affects homogeneous actors [56]. Marshall-type knowledge spillovers are useful for a firm who, to some extent, have a degree of technological proximity and/or absorptive capacity. Depending on the nature of knowledge spillovers, only some involved firms benefit from the new knowledge.

There are, to our knowledge, no papers concerning innovation in the solar, wind power or energy efficiency sector where the impact of technological knowledge externalities relative to employment effects has been identified. Aldieri and Vinci [37] analyse the sensitivity of employment with respect to own R\&D capital stock but also with respect to the technological R\&D spillovers, in high-tech and low-tech industries. They found that the employment effect of R\&D capital stock is mainly negative, and this result seems to indicate a prevalent destruction rate of the innovation process. The employment creation rate is not important enough or there is a hard reallocation of employment flows between the technology sectors.

As far as the technological spillover effects are concerned, only American high-tech firms benefited from local externalities, while the evidence that European high-tech firms benefit mainly from external spillovers could demonstrate that American firms are more specialised and mature. This finding could be consistent with the absorptive capacity hypothesis postulated by Cohen and Levinthal [39], which suggests that the degree to which firms benefit from external innovation is heavily dependent on their own investment in research. Aldieri and Vinci [61] show that the displacement effect is higher than the compensation effects.

As a technology develops, average observed job creation from the technology should decline since firms and employees are expected to have some amount of "learning-bydoing" [27,61]. A prominent example is "the Horndal effect" observed by the Swedish economist Erik Lundberg, who studied the iron mill Horndal in Dalarna. The iron mill did not make any significant investments in 15 years, yet production output rose two percent annually [62]. The productivity improvement, without more production factors, was explained by employee learning-by-doing. 
All else equal, technological improvements commonly reduce employment needed to produce the same output. A contra-balancing force is that when production becomes more efficient, the technology will be more feasible for new markets, which will increase demand. A reduction of any power plant construction price should increase construction [63].

Technological change in green energy price decreases has partly led to a scaling up of the power production facilities. Productivity improvements (leading to reduced costs) can pave the way to more wind power construction with less resources, leading to more total employment, even if the employment per unit of MWh is reduced [64-66].

Economies-of-scale and learning-by-doing are two factors that, theoretically, should have a large impact on job creation. Economies-of-scale will reduce worker intensity per unit of installed MWh the larger the project is. For learning-by-doing, consider two projects of the same size that are undertaken two decades apart; a different number of workers is expected in the later project $[12,67,68]$.

There are few comprehensive literature reviews focusing on employment effects from renewable energy. Aldieri et al. [22] assembled the literature between 2001 and 2019 which evaluated job effects of wind power construction and found employment effects from wind power construction but concluded that job creation can be limited and challenging in instances of case comparison. All wind power projects are undertaken under various institutional frameworks, labour markets, time periods and labour intensity within the respective countries. Labour intensity within a country also matters [69].

Another line of thought was presented by Ram et al. [70], who modelled global future job creation for renewable energy, and found that a large numerical job creation was to be expected from the transition to renewable energy sources, which would be larger than the expected job loss in the declining fossil industry. The notion that more jobs would be created in the transition than the ones lost in, for example, the coal and oil industry, was supported by Fragkos and Paroussos [13], who estimated that renewable energy would have higher labour intensity than fossil fuels. On the other hand, Frondel et al. [71] and Almutairi et al. [72] expected large job losses from a transition towards renewable and nuclear energy as the main component in the mix.

There is a distinction between types of job effects. There are direct, indirect and induced jobs. Direct jobs are the easiest jobs to identify, and can, for example, be found in the manufacturing of key components, power plant construction and operation and maintenance (O\&M), i.e., a worker building a green energy component in a factory can be defined as having a job due to green energy demand [12,73-75]. Some studies include jobs in, for example, project management, research and development, energy companies, utilities and banks.

Indirect jobs are more ambiguous. Scholars have estimated indirect jobs by inputoutput analysis to evaluate indirect effects of materials and services on the upstream supply chain. Consultancies and several minor components not directly linked to the sector matters and should be considered. Some research distinguishes between indirect jobs and induced jobs. Induced jobs can materialise as a by-product of spending (e.g., salaries) from direct and indirect employment [76-78]. These induced effects appeared in some research [79-82].

\section{Methods}

Knowledge spillovers are typically measured as the stock of R\&D conducted outside the focal firm and weighted by some measure of closeness between the source and the recipient of the spillovers. Jaffe [83] assumes that the closer two firms are in the technological space, the more likely a firm will be affected by the spillovers generated by the "nearby" firm. The Jaffe measure constructs a technological vector for each firm based on the distribution of its patents across different classes of technology [57].

These vectors allow one to locate firms into a multi-dimensional technological space where technological proximity between firms are proxied by the uncentered correlation coefficient between the corresponding technology vectors. Since Jaffe's measure is relative 
only to spillovers within the same technology sector, and rules out spillovers between different sectors, the Mahalanobis norm is developed [84], where the uncentered correlation index between different technology sectors is also identified. Both the externalities generated in the same sector-specialised, Marshallian or intra-industry spillovers, and spillovers, generated by firms belonging to the different sector, defined as inter-industry, diversified or Jacobian Spillovers [26-28] are investigated. Because of the presence of two contrasting effects: negative displacement effect and positive compensation effect, theoretical prediction cannot identify which effect could prevail. Thus, the empirical framework is needed. However, a theoretical model is presented in the Appendix A. It could be useful to explain the different result from specialised or diversified spillovers because the sign of the externalities impact could depend on the competitive level, measured by the parameters.

In order to evaluate the effect of technological change in the green energy sector on efficiency indicator, a twofold procedure is employed: (i) the technical efficiency is estimated through data envelopment analysis (DEA) [85]; (ii) the tobit model [86] allows to identify the knowledge spillovers' impact on efficiency score. In particular, the DEA is a method commonly used in the energy field [87-91]. In particular, the technological productivity is computed with the Malmquist index, which measures the productivity changes along with time variations, where output variable is the ratio between sales and number of employees. [92,93].

In the first step, the DMUs provide the frontier from which the efficiency parameters are computed. Every deviation from the frontier leads to inefficiency. DMUs are grouped on the basis of the energy patents per country and per year, so we can develop a dynamic model, useful to shed further light on the employment effects of energy innovation.

As DEA efficiency scores are continuous on the interval $[0,1]$, in the second step, the tobit model [86] is used to estimate the linear relationship between the efficiency score as the dependent variable, and the Marshallian and Jacobian spillovers stemmed from R\&D investments in the energy and wind field. Stata 16 software has been used for the empirical results.

\section{Data}

The OECD's REGPAT database from January 2018 (please contact Helene.DERNIS@ oecd.org to download the REGPAT database) [94] is employed. These data regard patent applications to the European Patent Office (EPO) published up to December 2017. There is a publication lag in the database, which results in later years missing from the data and hence the cut off from 2017. Renewable energy power patents for measuring green economy activity are identified. The positive relationship between $R \& D$ expenditure and patenting has been recognised in several microeconomic studies [95-97].

Bruns and Kalthaus [97] highlighted several renewable energy patent studies containing over 51 patent assembling methods, hence our considerations are the following. The patent data were derived from the OECD Environment Directorate, who collaborate with the Directorate for Science, Technology, and Innovation. The OECD Environment Directorate have constructed patent-based innovation indicators to track developments in environment-related technologies. The statistic originates from the Worldwide Patent Statistical Database (PATSTAT) of the European Patent Office (EPO), the OECD developed and used algorithms to extract the data. Consistent with other patent statistics provided in OECD.Stat, only published applications for "patents of invention" are considered (i.e., excluding utility models, petty patents, etc.).

There is a large amount of literature with conceptual criticisms against the use of patent data as a measure of invention output $[45,98,99]$. However, patent data have been frequently applied as approximations of the impact of technological change and invention, and for our purpose, the variable should be appropriate [100].

Innovations in the context of green energy have been identified based on opportune patent codes (http:/ / www.oecd.org/env/consumption-innovation/indicator.htm 
(accessed on 10 June 2018)), as in Marin and Lotti [100]. In Table 1, the clusters of energy patents are presented.

Table 1. Patent codes.

\begin{tabular}{cc}
\hline Macro Category & IPC \\
\hline & \\
Fuel efficiency & F01M, F01N, F02B, F02D, F02M, G01M, B01D, B01J, B60, \\
Energy & B62D, F02B, F02M, F01N, F02D, G01M, F02P, B62D, B60C, \\
& B60T, B60G, B60K, B60W, B60K, B60L, B60R, B60S, B60W, \\
& F04B, E06B, F24D, B60K, B60W, H01J, H05B \\
\hline & H01L, H01G, H02N, C01B, C23C, C30B, G05F, F21L, F21S, \\
& H02J, H01H, H01M, F24J, E04D, F22B, F25B, F26B, G02B, \\
Solar and wind energy & F03D, H02K, B63B, F01K, F24F, F24J, H02N, F25B, F03G \\
& E04H, B60K, B60L, B63H \\
\hline
\end{tabular}

As seen in Table 1, the technological proximity between the classes for energy production efficiency is explored, and the context of renewable energy is analysed.

The technological development and diffusion abilities are believed to depend primarily on three factors: (a) invention infrastructure such as R\&D employees or R\&D expenditures as previous innovation engagement [51,52]; (b) technological and economic specialisation [101-103] and (c) the quality of the innovation infrastructure [104].

The following variables relative to sales (S), labour (L), physical capital (C) and R\&D (RD) from the EU Scoreboard [103] are selected. The wages are measured through capital expenditures and operating profits [104]. All variables are converted into constant 2000 euros, according to the GDP deflator. The stock of R\&D capital based on the permanent inventory method [55] is computed by assuming a 15 percent depreciation rate and a 5 percent growth rate [105].

In order to measure the diversity degree between the firms, the procedure introduced by Jaffe [83] is followed. In particular, the technological proximities can be performed as:

$$
T_{i j}=\frac{\sum_{k=1}^{K} P_{i k} P_{j k}}{\sqrt{\sum_{k=1}^{K} P_{i k}^{2} \sum_{k=1}^{K} P_{j k}^{2}}}
$$

where $P_{i}$ indicates the patent distribution over the technology fields for firm $i$ and $T_{i j}$ represents the technological relatedness between firms $j$ and $i$. Since Jaffe's measure computes the spillovers only within the same field, we employed the Mahalanobis approach, so we took into account also the spillovers between different fields [31]:

$$
\hat{P}=T \Omega T^{\prime}
$$

where $\Omega$ is the correlation index between energy technology fields.

Finally, the technological knowledge spillovers are measured in the following way:

$$
T S_{i}=\sum_{i \neq j} \hat{P}_{i j} K_{j}
$$

where $K_{j}$ is relative to the R\&D capital stock of firm $j$, as discussed by Aldieri et al. [31]. In Table 2, the summary statistics of the data sample is presented: 
Table 2. Data statistics.

\begin{tabular}{|c|c|c|}
\hline Variable & Mean ${ }^{a}$ & Std. Dev. \\
\hline Log (Net Sales) & 8.69 & 1.793 \\
\hline $\log ($ Labor $)$ & 9.15 & 2.746 \\
\hline Log (Marshallian Spillovers) & 3.33 & 2.214 \\
\hline Log (Jacobian Spillovers) & 3.86 & 2.571 \\
\hline Log (Physical Capital) & 7.10 & 2.116 \\
\hline Log (R\&D capital) & 6.92 & 1.874 \\
\hline
\end{tabular}

a: $n=2277$ observations.

\section{Results}

Table 3 reports DEA model results, in which technical efficiency based on the Malmquist productivity index is performed both for American and European firms. Since the sample is made up of data from large international companies, it is reasonable to observe high levels of efficiency (achieved if the estimated parameter is equal to 1.00).

To investigate to what extent the process of spreading technological knowledge produces a significant impact on the distance from technical efficiency on the frontier, we proceed to estimate the tobit model, where the dependent variable is represented by the parameter of Malmquist technical efficiency and the Marshallian and Jacobian spillovers components represent the explanatory variables. Additionally, other studies apply the two-step regression procedure to relate DEA scores and spillovers [106]. Firstly, we run tobit analysis to all countries for all years (Table 4). Secondly, because we can observe a large drop in score in 2017, we re-estimate the model by excluding 2017-year data in Table 5. Finally, we estimate panel fixed effect to overcome the problem of few observations (Table 6).

Table 3. DEA models of the technical efficiency.

\begin{tabular}{|c|c|c|c|c|c|c|c|c|c|c|}
\hline \multicolumn{11}{|c|}{ Technical Efficiency } \\
\hline Year & USA & Belgium & Denmark & Finland & France & Germany & Italy & Sweden & Netherlands & UK \\
\hline 2002 & 1.00 & 0.99 & 0.99 & 1.00 & 0.96 & 1.00 & 0.99 & 0.99 & 1.00 & 0.99 \\
\hline 2003 & 1.00 & 0.99 & 1.00 & 1.00 & 0.96 & 1.00 & 0.99 & 1.00 & 1.00 & 0.99 \\
\hline 2004 & 0.99 & 1.00 & 1.00 & 0.99 & 1.00 & 1.00 & 0.99 & 0.99 & 0.33 & 1.00 \\
\hline 2005 & 1.00 & 0.99 & 0.99 & 1.00 & 0.96 & 1.00 & 0.99 & 0.99 & 0.33 & 1.00 \\
\hline 2006 & 1.00 & 0.99 & 0.99 & 1.00 & 0.97 & 0.97 & 0.99 & 1.00 & 0.99 & 1.00 \\
\hline 2007 & 1.00 & 0.99 & 1.00 & 0.99 & 1.00 & 1.00 & 0.99 & 1.00 & 1.00 & 1.00 \\
\hline 2008 & 0.99 & 1.00 & 1.00 & 0.98 & 1.00 & 0.99 & 0.98 & 0.98 & 0.99 & 0.97 \\
\hline 2009 & 0.98 & 0.98 & 0.99 & 0.98 & 0.98 & 0.99 & 0.98 & 0.98 & 0.98 & 0.99 \\
\hline 2010 & 0.98 & 1.00 & 0.99 & 1.00 & 0.97 & 0.97 & 0.98 & 0.98 & 0.97 & 1.00 \\
\hline 2011 & 0.79 & 0.75 & 0.86 & 0.84 & 0.47 & 0.75 & 0.78 & 0.77 & 0.78 & 0.47 \\
\hline 2012 & 1.00 & 0.96 & 0.99 & 0.98 & 0.53 & 0.99 & 0.99 & 1.00 & 0.97 & 0.77 \\
\hline 2013 & 0.99 & 0.98 & 0.98 & 0.97 & 0.99 & 0.96 & 0.98 & 0.96 & 0.98 & 0.95 \\
\hline 2014 & 0.99 & 0.81 & 0.99 & 0.96 & 0.99 & 1.00 & 0.93 & 0.99 & 0.94 & 0.93 \\
\hline 2015 & 0.96 & 1.00 & 1.00 & 0.99 & 0.95 & 0.94 & 1.00 & 1.00 & 0.99 & 0.99 \\
\hline 2016 & 0.70 & 0.80 & 0.72 & 0.81 & 0.80 & 0.90 & 0.82 & 0.79 & 0.70 & 0.94 \\
\hline 2017 & 0.57 & 0.59 & 0.58 & 0.64 & 0.63 & 0.66 & 0.59 & 0.63 & 0.54 & 0.61 \\
\hline
\end{tabular}

Table 4. Tobit regression: all countries 2002-2017 (average marginal effects).

\begin{tabular}{ccc}
\hline Dependent Variable: Efficiency Score & Estimate & Robust S.E. \\
\hline logMARSpillovers & $-0.006^{* *}$ & $(0.002)$ \\
logJSpillovers & $0.008^{*}$ & $(0.003)$ \\
\hline Number of obs. & & 150 \\
F (2,148) & & 4.80 \\
$p$-value F & & 0.0096 \\
Pseudo-R2 & & 0.0830 \\
\hline
\end{tabular}


Table 5. Tobit regression: all countries 2002-2016 (average marginal effects).

\begin{tabular}{ccc}
\hline Dependent Variable: Efficiency Score & Estimate & Robust S.E. \\
\hline logMARSpillovers & $-0.005^{* *}$ & $(0.002)$ \\
logJSpillovers & $0.007^{* *}$ & $(0.003)$ \\
\hline Number of obs. & & 140 \\
F $(2,138)$ & & 4.09 \\
$p$-value F & & 0.0188 \\
Pseudo-R2 & 0.0574 \\
\hline
\end{tabular}

Note: ${ }^{* *}$ coefficient significant at $5 \%$ level.

Table 6. Fixed Effect regression: all countries 2002-2017.

\begin{tabular}{|c|c|c|}
\hline Dependent Variable: Efficiency Score & Estimate & Robust S.E. \\
\hline logMARSpillovers & $-0.003^{* *}$ & $(0.001)$ \\
\hline $\operatorname{logJSpillovers~}$ & $0.065^{* * *}$ & $(0.037)$ \\
\hline Number of obs. & & 150 \\
\hline $\mathrm{F}(2,138)$ & & 5.24 \\
\hline$p$-value $\mathrm{F}$ & & 0.0096 \\
\hline Pseudo-R2 & & 0.0705 \\
\hline
\end{tabular}

Table 7 evidences the findings relative to the impact of spillovers on the efficiency score by country. From the tobit regressions in average marginal effects, evidence is found that Marshallian spillovers have a negative impact and Jacobian spillovers have a positive one on the American and European firm's efficiency score (Table 7). The tobit model is statistically confirmed by F-test.

Table 7. Tobit regression by country (average marginal effects).

\begin{tabular}{|c|c|c|c|c|c|c|c|c|c|c|}
\hline \multicolumn{11}{|c|}{ Dependent Variable: Efficiency Score } \\
\hline & USA & Belgium & Denmark & Finland & France & Germany & Italy & Sweden & Netherlands & UK \\
\hline logMARSpillovers & $-0.25^{* *}$ & $-0.87^{*}$ & 0.31 & $-0.59 * *$ & -0.02 & -0.04 & 0.05 & 0.22 & 0.28 & -0.48 \\
\hline logJSpillovers & 0.08 & 0.05 * & 0.02 & 0.01 & 0.28 & 0.54 * & 0.06 & 0.29 & 0.30 & 0.91 \\
\hline Number of obs. & 15 & 15 & 15 & 15 & 15 & 15 & 15 & 15 & 15 & 15 \\
\hline$F(2,13)$ & 4.36 & 7.08 & 1.76 & 2.49 & 0.13 & 3.42 & 3.63 & 1.15 & 1.6 & 1.21 \\
\hline$p$-value $\mathrm{F}$ & 0.0264 & 0.0083 & 0.2063 & 0.1216 & 0.8772 & 0.064 & 0.056 & 0.3483 & 0.2392 & 0.33 \\
\hline
\end{tabular}

Note: ${ }^{*}{ }^{* *}$ coefficient significant at $1 \%, 5 \%$ level.

The negative findings relative to spillovers could also be explained through the negative externalities that the own production process can determine from the common environment, and then on the resources available for other firms and useful for their activity [107]. The lower quality of the environment leads to a lower performance of the innovation process of the other companies.

Moreover, since the tobit model is questionable [108], we also used OLS regression as a robustness check. The models are comparable because tobit results are in average marginal effects. Table 8 confirms the negative impact of Marshallian spillovers and the positive effect of Jacobian ones, where significant.

Table 8. OLS regression by country.

\begin{tabular}{|c|c|c|c|c|c|c|c|c|c|c|}
\hline \multicolumn{11}{|c|}{ Dependent Variable: Efficiency Score } \\
\hline & USA & Belgium & Denmark & Finland & France & Germany & Italy & Sweden & Netherlands & UK \\
\hline logMARSpillovers & $-0.11 *$ & $-0.78 * *$ & 0.22 & $-0.17 * *$ & -0.23 & -0.08 & -0.01 & -0.75 & $-0.19 *$ & -0.66 \\
\hline logJSpillovers & $0.65 *$ & $0.24 *$ & 0.01 & 0.25 & $0.14 *$ & 0.66 & 0.18 & $0.25 *$ & $0.19 *$ & $0.16^{* *}$ \\
\hline Number of obs. & 15 & 15 & 15 & 15 & 15 & 15 & 15 & 15 & 15 & 15 \\
\hline$R^{2}$ & 0.86 & 0.46 & 0.42 & 0.47 & 0.04 & 0.06 & 0.06 & 0.47 & 0.73 & 1.21 \\
\hline
\end{tabular}

Note: ${ }^{*}{ }^{* *}$ coefficient significant at $1 \%, 5 \%$ level. 


\section{Discussion}

The findings indicate statistically significant Marshallian spillovers effects on employment. From a theoretical economics perspective, the finding of negative employment effects of Marshallian spillovers has a sound grounding. In particular, the spillovers from the same technology sector (Marshallian externalities) have a negative effect on job creation, in line with the empirical evidence concerning environmental innovations and firms' competitiveness [109]. However, the findings were weakly statistically significant and did not occur in all countries; this could be because of the rather crude measure and data level used, but it does show the presence of these spillovers.

The finding of positive statistically significant job effects from Jacobian spillovers is in line with previous literature, which found that knowledge spillovers across seemingly unrelated technologies also occur, and firms/countries can profit from distant technologies [33-37]. Intra-technology spillovers can come from technological variety where unforeseen effects can have a substantial and positive impact on the general development and can therefore be one potential goal of technology policy [110]. However, the findings were weakly statistically significant and did not occur in all countries.

The idea from the theoretical model is that specialised sectors have a lower competitive level, and thus they experience a prevailing displacement effect, while diversified sectors, living in a more competitive context, generate a higher compensation effect. In general, theoretical terms, if a firm or a country lack capabilities to assimilate new knowledge, spillovers will appear at a sub-optimal level. The internal absorptive capacity is vital for a capacity to transform imported technology into productivity gains in a production apparatus. Hence, the ability to receive technological spillovers or use advancements is a function of previous experience in $\mathrm{R} \& \mathrm{D}$; if there is no absorptive capacity then the spillover flow might not exist [39]. Previous literature on technological change has emphasised the cumulative character of knowledge for further technological improvements and usage $[55,111]$. Indeed, absorptive capacity provides positive and significant impact in an energy context [112-116].

Pursuing low unemployment and expansion of renewable energy as policy targets simultaneously is a suboptimal strategy. Böhringer and Rosendahl [117] showed that environmental externalities are best targeted through Pigouvian emission taxes_-additional targets for renewable energy can be redundant and costly. A pursuit of several targets calls for an equalisation of the number of policy instruments with the number of policy targets [116]. Good intentions do not always give good policy outcomes, and scepticism exists against the thought of any (including renewable) promotion policies that will lead to a clear-cut win-win outcome.

For the energy supply within a country, the obtained results in this paper are rather positive. A policy maker could previously doubt that resources such as labour would be enough to sustain the rapid green energy. There will, of course, be a risk for bottlenecks, but the results in this paper indicate that less labour will be needed for the same amount of energy supply construction, and hence there is a higher chance that the countries that are trying to remodel their energy systems and become more energy efficient will be successful.

Finally, a word on public policy and promotion of green energy jobs. There is a tradeoff between economic efficiency and labour market effects. Böhringer et al. [118] showed that initial labour market rigidities have the potential to provide some scope for a double dividend in terms of positive labour market effects derived from government subsidies. Dynamic effects of a changing economic structure and of technological change matters where increasing productivity can increase output with the same level of employment. General factors, such as budget effects on household incomes or reduced imports of fossil fuels and other goods, should also be considered [119].

\section{Conclusions and Policy Implications}

It was not previously clear if Marshallian and Jacobian spillover effects within the green energy field affected employment. The empirical findings suggest that there were neg- 
ative employment spillovers from the same technology sector (Marshallian externalities), while there were positive spillovers from more diversified activity (Jacobian externalities). For policy makers, who count on employment effects, these results must imply some downward revisions. Over time, employment could decline ceteris paribus. When it comes to job creation, policy makers should lower their expectation for future gains. There will be employment, but for every new MW installed, job creation for constructing the next could go down slightly.

These findings have important policy implications, as policy makers can use them to identify the best instruments to maximise the economic benefits from energy innovation. When it comes to spillovers, policy makers should promote green energy expansion and R\&D investment, since today's investments will make further projects less labour-intensive tomorrow.

On a general level, there are implications for the literature on technological change that can be derived from the presented results. The results are relevant to incorporate into technology forecasting models, which might undervalue technological change if the models fail to consider inter-technology flows. Technology forecasting models are central for scientific efforts, such as integrated assessment models produced by the Intergovernmental Panel on Climate Change. Considering the results of the present paper, especially with respect to the knowledge flows across technologies that are related to each other, these models might have to be adapted to reflect inter-technology learning effects.

However, further analysis concerning technical efficiency in energy field is needed to obtain deeper comprehension of the mechanisms relative to knowledge flows. Indeed, outstanding questions include whether these results are externally valid or if they have external validity to other energy fields.

Author Contributions: Formal analysis, L.A.; Investigation, J.G.; Methodology, L.A.; Supervision, C.P.V.; writing — original draft preparation, L.A.; writing - review and editing, J.G. and C.P.V. All authors have read and agreed to the published version of the manuscript.

Funding: This research received no external funding.

Conflicts of Interest: The authors declare no conflict of interest.

\section{Appendix A}

In line with Garcia et al. [119], a multi-sector economy is considered where firms' production combines physical, human and knowledge capital with a variety of different green energy: wind, geothermal, solar, integrated emissions control, water pollution abatement, solid waste collection. Production level at time $t$ of field $i,\left(Y^{i}\right)$ is the combination of two different outputs from two different production technologies: a green $\left(Y_{G}^{i}\right)$, where further separation techniques adopting exclusively wind power energy $\left(Y_{G W}^{i}\right)$ from other forms of green energies $\left(Y_{G E}^{i}\right)$, and $\left(Y_{N}^{i}\right)$, and written as:

$$
\begin{gathered}
Y_{G}^{i}=\alpha Y_{G W}^{i}+(1-\alpha) Y_{G E}^{i}(1) \text { with } 0<\alpha<1 \\
Y^{i}=\beta Y_{N}^{i}+(1-\beta) Y_{G}^{i}(2) \text { with } 0<\beta<1 \\
Y^{i}=\beta Y_{N}^{i}+(1-\beta)\left[\alpha Y_{G W}^{i}+(1-\alpha) Y_{G E}^{i}\right]
\end{gathered}
$$

where:

$$
\begin{gathered}
Y_{G E}^{i}=Y_{G}^{i}\left(C, K_{G E}, L\right) \\
Y_{G W}^{i}=Y_{G W}^{i}\left(C, K_{G W}, L\right) \\
Y_{N}^{i}=Y_{N}^{i}\left(C, K_{N}, L\right)
\end{gathered}
$$

In Equations (A4)-(A6), variables $C, L$ measure, respectively, physical capital and labour, while the innovation effects of different production techniques: green, wind green and not green, are, respectively, embodied in the knowledge capital levels $K_{N}, K_{G}$ and $K_{G W}$. 
As in the findings of Aldieri and Vinci [27], the $i$ sector's firms are assumed to compete in differentiated output markets, minimise costs with constant returns to scale technologies and invest in R\&D for process and product innovation. Moreover, the innovation effects on technology and the demand function are embodied in the knowledge capital.

Stating one-to-one, $c$ and $w$ capture the marginal cost and the vector inputs prices, stating that $c=c\left(w, K_{G E}, K_{G W}, K_{N t}\right)$. Moreover, $p$ is defined as the output price, $\mu$ the mark-up, $d^{e}$ indicates the market dynamics and finally $K_{G E}^{R}, K_{G W}^{R}, K_{N}^{R}, p_{R}, L_{R}$, respectively, capture the rival firms' accumulated knowledge capitals, output prices and employment.

Stating what follows:

$$
\begin{gathered}
p=(1+\mu) c\left(w, K_{G E}, K_{G W}, K_{N}\right) \\
Y=D\left(d^{e}, p, p_{R}, K_{G E}, K_{G W}, K_{N}, K_{G E}^{R}, K_{G W}^{R}, K_{N}^{R}\right) \\
K_{N}^{R}=g\left(K_{N}\right) \\
K_{G E}^{R}=g\left(K_{G E}\right) \\
K_{G W}^{R}=g\left(K_{G W}\right) \\
L=c_{L}\left(w, K_{G E}, K_{G W}, K_{N}\right) Y \\
p_{R}=\left(1+\mu_{R}\right) c_{R}\left(w_{R}, K_{G E}^{R}, K_{G W}^{R}, K_{N}^{R}\right)
\end{gathered}
$$

where $c_{L}$ captures the marginal cost derivative respect employment (the Shepard's lemma), and parameters $c_{R}, w_{R}, \mu_{R}$ denote the rival firms' marginal cost, vector inputs prices and mark-up.

Equation (A12) can be written as:

$$
L=c_{L}\left(w, K_{G E}, K_{G W}, K_{N}\right) D\left(d^{e},(1+\mu) c\left(w, K_{G E}, K_{G W}, K_{N}\right),\left(1+\mu_{R}\right) c_{R}\left(w_{R}, K_{G E}^{R}, K_{G W}^{R}, K_{N}^{R}\right), K_{G E}, K_{G}, K_{N}, K_{G}^{R}, K_{G W}^{R}, K_{N}^{R}\right)
$$

From inspection of the above, the short run innovation effects on the labour input will be captured by the following:

$$
\begin{gathered}
\frac{\partial L}{\partial K_{N}}=\frac{\partial c_{L}}{\partial K_{N}} Y+c_{L}\left\{\frac{\partial Y}{\partial K_{N}}+\frac{\partial Y}{\partial p} \frac{\partial p}{\partial K_{N}}+\frac{\partial Y}{\partial p_{R}} \frac{\partial p_{R}}{\partial K_{N}^{R}} \frac{\partial K_{N}^{R}}{\partial K_{N}}+\frac{\partial Y}{\partial K_{N}^{R}} \frac{\partial K_{N}^{R}}{\partial K_{N}}\right\} \\
\frac{\partial L}{\partial K_{G}}=\frac{\partial c_{L}}{\partial K_{G}} Y+c_{L}\left\{\frac{\partial Y}{\partial K_{G}}+\frac{\partial Y}{\partial p} \frac{\partial p}{\partial K_{G}}+\frac{\partial Y}{\partial p_{R}} \frac{\partial p_{R}}{\partial K_{G E}^{R}} \frac{\partial K_{G E}^{R}}{\partial K_{G}}+\frac{\partial Y}{\partial K_{N}^{R}} \frac{\partial K_{G E}^{R}}{\partial K_{G}}\right\} \\
\frac{\partial L}{\partial K_{G W}}=\frac{\partial c_{L}}{\partial K_{G W}} Y+c_{L}\left\{\frac{\partial Y}{\partial K_{G W}}+\frac{\partial Y}{\partial p} \frac{\partial p}{\partial K_{G W}}+\frac{\partial Y}{\partial p_{R}} \frac{\partial p_{R}}{\partial K_{G W}^{R}} \frac{\partial K_{G W}^{R}}{\partial K_{G W}}+\frac{\partial Y}{\partial K_{G W}^{R}} \frac{\partial K_{G W}^{R}}{\partial K_{G W t}}\right\}
\end{gathered}
$$

The first terms of the right-hand sides of the above three equations measure the displacement effects, respectively, for the three types of innovations, standard, green and wind power green energies. Other terms on the right-hand side of Equations (A15)-(A17) take, for the above three different innovation categories, the additional compensation results:

- Production innovation effects on the total demand;

- Demand effects through cost fall due to price decline;

- Demand effects of rival firms' price variations via the innovations of competitors;

- Demand effects of the innovations of competitors.

Because of wages bargaining, prices dynamics variations via $\mu$ and $\mu_{R}$ may occur and contemplate with $z$ and $z_{R}$ further possible changes on wages and mark-ups, stating:

$$
w=w\left(z, C, K_{G E}, K_{G W}, K_{N}\right)
$$




$$
\begin{gathered}
w_{R}=w_{R}\left(z_{R}, C_{R}, K_{G E}^{R}, K_{G W}^{R}, K_{N}^{R}\right) \\
\mu=\mu\left(z, C, K_{G E}, K_{G W}, K_{N}\right) \\
\mu_{R}=\mu_{R}\left(z_{R}, C_{R}, K_{G E}^{R}, K_{G W}^{R}, K_{N}^{R}\right)
\end{gathered}
$$

Hence, the short-run innovation effects on the employment levels will be turned into:

$$
\begin{aligned}
& \frac{d L}{d K_{N}}=\left[\begin{array}{ll}
\frac{\partial c_{L}}{\partial K_{N}} & +\frac{\partial c_{L}}{\partial w} \frac{\partial w}{\partial K_{N}}
\end{array}\right] Y \\
& +c_{L}\left\{\frac{\partial Y}{\partial K_{N}}\right. \\
& +\frac{\partial Y}{\partial p}\left\{\frac{\partial p}{\partial \mu} \frac{\partial \mu}{\partial K_{N}} c\right. \\
& \left.+(1+\mu)\left[\frac{\partial c}{\partial w} \frac{\partial w}{\partial K_{N}}+\frac{\partial c}{\partial K_{N}}\right]\right\} \frac{\partial Y}{\partial p_{R}}\left[c_{R}\left\{\frac{\partial \mu_{R}}{\partial K_{N}^{R}} \frac{\partial K_{N}^{R}}{\partial K_{N}}\right\}+(1\right. \\
& \left.\left.\left.+\mu_{R}\right)\left\{\frac{\partial c_{R}}{\partial w_{R}} \frac{\partial w_{R}}{\partial K_{N}^{R}} \frac{\partial K_{N}^{R}}{\partial K_{N}}+\frac{\partial c_{R}}{\partial K_{N}^{R}} \frac{\partial K_{N}^{R}}{\partial K_{N}}\right\}\right]+\frac{\partial Y}{\partial K_{N}^{R}} \frac{\partial K_{R}}{\partial K_{N}}\right\}
\end{aligned}
$$

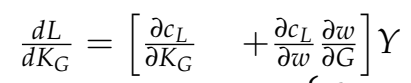

$$
\begin{aligned}
& +c_{L}\left\{\frac{\partial Y}{\partial K_{G}}\right. \\
& +\frac{\partial Y}{\partial p}\left\{\frac{\partial p}{\partial \mu} \frac{\partial \mu}{\partial K_{G}} c\right. \\
& \left.+(1+\mu)\left[\frac{\partial c}{\partial w} \frac{\partial w}{\partial K_{G}}+\frac{\partial c}{\partial K_{G}}\right]\right\} \frac{\partial Y}{\partial p_{R}}\left[c_{R}\left\{\frac{\partial \mu_{R}}{\partial K_{G}^{R}} \frac{\partial K_{G}^{R}}{\partial K_{G}}\right\}+(1\right. \\
& \left.\left.\left.+\mu_{R}\right)\left\{\frac{\partial c_{R}}{\partial w_{R}} \frac{\partial w_{R}}{\partial K_{N}^{R}} \frac{\partial K_{G}^{R}}{\partial K_{G}}+\frac{\partial c_{R}}{\partial K_{G}^{R}} \frac{\partial K_{G}^{R}}{\partial K_{G}}\right\}\right]+\frac{\partial Y}{\partial K_{G}^{R}} \frac{\partial K_{G}^{R}}{\partial K_{G}}\right\} \\
& \frac{d L}{d K_{G W}}=\left[\frac{\partial c_{L}}{\partial K_{G W}} \quad+\frac{\partial c_{L}}{\partial w} \frac{\partial w}{\partial K_{G W}}\right] Y \\
& +c_{L}\left\{\frac{\partial Y}{\partial K_{G W}}\right. \\
& +\frac{\partial Y}{\partial p}\left\{\frac{\partial p}{\partial \mu} \frac{\partial \mu}{\partial K_{G W}} c\right. \\
& \left.+(1+\mu)\left[\frac{\partial c}{\partial w} \frac{\partial w}{\partial K_{G W}}+\frac{\partial c}{\partial K_{G W}}\right]\right\} \frac{\partial Y}{\partial p_{R}}\left[c_{R}\left\{\frac{\partial \mu_{R}}{\partial K_{G W}^{R}} \frac{\partial K_{G W}^{R}}{\partial K_{G W}}\right\}+(1\right. \\
& \left.\left.\left.+\mu_{R}\right)\left\{\frac{\partial c_{R}}{\partial w_{R}} \frac{\partial w_{R}}{\partial K_{G W}^{R}} \frac{\partial K_{G W}^{R}}{\partial K_{G W}}+\frac{\partial c_{R}}{\partial K_{G W}^{R}} \frac{\partial K_{G W}^{R}}{\partial K_{G W}}\right\}\right]+\frac{\partial Y}{\partial K_{G W}^{R}} \frac{\partial K_{G W}^{R}}{\partial K_{G W}}\right\}
\end{aligned}
$$

\section{References}

1. European Parliament; Council of the European Union. Directive 2009/28/EC of the European Parliament and of the Council of 23 April 2009 on the promotion of the use of energy from renewable sources and amending and subsequently repealing Directives 2001/77/EC and 2003/30/EC. Off. J. Eur. Union 2009, L 140, 16.

2. European Commission. Clean Energy for all Europeans; European Commission: Brussels, Belgium, 2016; Winter package.

3. European Commission. Employment and Social Developments in Europe 2019; European Commission: Brussels, Belgium, 2019.

4. European Commission. Green Employment Initiative: Tapping into the Job Creation Potential of the Green Economy; European Commission: Brussels, Belgium, 2014; COM (2014) 446 final.

5. Garrett-Peltier, H. Green versus brown: Comparing the employment impacts of energy efficiency, renewable energy, and fossil fuels using an input-output model. Econ. Model 2017, 61, 439-447. [CrossRef]

6. Fankhaeser, S.; Sehlleier, F.; Stern, N. Climate change, innovation and jobs. Clim. Policy 2008, 8, 421-429. [CrossRef]

7. Apergis, N.; Payne, J.E. Renewable energy consumption and economic growth: Evidence from a panel of OECD countries. Energy Policy 2010, 38, 656-660. [CrossRef]

8. Horbach, J. The impact of innovation activities on employment in the environmental sector-Empirical results for Germany at the firm level. J. Econ. Stat. 2010, 230, 403-419. [CrossRef]

9. Mathiesen, B.V.; Lund, H.; Karlsson, K. 100\% renewable energy systems, climate mitigation and economic growth. Appl. Energy 2011, 88, 488-501. [CrossRef]

10. Simas, M.; Pacca, S. Assessing employment in renewable energy technologies: A case study for wind power in Brazil. Renew. Sustain. Energy Rev. 2014, 31, 83-90. [CrossRef]

11. Horbach, J.; Rennings, K. Environmental innovation and employment dynamics in different technology fields—An analysis based on the German Community Innovation Survey 2009. J. Clean. Prod. 2013, 57, 158-165. [CrossRef] 
12. Cameron, L.; van der Zwaan, B. Employment factors for wind and solar energy technologies: A literature review. Renew. Sustain. Energy Rev. 2015, 45, 160-172. [CrossRef]

13. Fragkos, P.; Paroussos, L. Employment creation in EU related to renewables expansion. Appl. Energy 2018, 230, 935-945. [CrossRef]

14. Ram, M.; Aghahosseini, A.; Breyer, C. Job creation during the global energy transition towards $100 \%$ renewable power system by 2050. Technol. Forecast. Soc. Chang. 2020, 151, 1-19. [CrossRef]

15. Aldieri, L.; Kotsemir, M.N.; Vinci, C.P. The role of geographic spillovers in employment policy planning: An empirical investigation for Russian regions. Foresight 2018, 20, 289-311. [CrossRef]

16. Aldieri, L.; Kotsemir, M.N.; Vinci, C.P. The impact of environmental innovations on job-creation process: An empirical investigation for Russian regions. Environ. Econ. Policy Stud. 2018. [CrossRef]

17. Awan, U.; Munir, G.; Farid, S. Work satisfaction aspects in academics: An empirical study. World Appl. Sci. J. 2013, 28 , $2193-2201$.

18. Van Roy, V.; Vértesy, D.; Vivarelli, M. Technology and employment: Mass unemployment or job creation? Empirical evidence from European patenting firms. Res. Policy 2018, 47, 1762-1776. [CrossRef]

19. Pellegrino, G.; Piva, M.; Vivarelli, M. Beyond R\&D: The role of embodied technological change in affecting employment. J. Evol. Econ. 2019, 29, 1151-1171.

20. Mazzanti, M.; Zoboli, R. Environmental efficiency and labour productivity: Trade-off or joint dynamics? A theoretical investigation and empirical evidence from Italy using NAMEA. Ecol. Econ. 2009, 68, 1182-1194. [CrossRef]

21. Costantini, V.; Crespi, F.; Paglialunga, E. The employment impact of private and public actions for energy efficiency: Evidence from European industries. Energy Policy 2018, 119, 250-267. [CrossRef]

22. Aldieri, L.; Grafström, J.; Sundström, K.; Vinci, C.P. Wind power and job creation. Sustainability 2020, 12, 45. [CrossRef]

23. Dell'Anna, F. Green jobs and energy efficiency as strategies for economic growth and the reduction of environmental impacts. Energy Policy 2021, 149, 112031. [CrossRef]

24. IRENA. Renewable Energy and Jobs-Annual Review 2020. 2020. Available online: https://www.irena.org//media/Files/ IRENA/Agency/Publication/2020/Sep/IRENA_RE_Jobs_2020.pdf. (accessed on 15 June 2021).

25. Popp, D.; Vona, F.; Marin, G.; Chen, Z. The Employment Impact of Green Fiscal Push: Evidence from the American Recovery Act; National Bureau of Economic Research: Cambridge, MA, USA, 2020; Working Paper No. 27321.

26. Marshall, A. Principles of Economics; Macmillan: London, UK, 1890.

27. Arrow, K.J. The economic implications of learning by doing. Rev. Econ. Studies 1962, 29, 155-172. [CrossRef]

28. Romer, P.M. Increasing returns and long-run growth. J. Political Econ. 1986, 94, 1002-1037. [CrossRef]

29. Glaeser, S.; Kallal, H.D.; Scheinkman, J.A.; Shleifer, A. Growth of cities. J. Political Econ. 1992, 100, 1126-1152. [CrossRef]

30. Jacob, J. The Economy of Cities; Random House: New York, NY, USA, 1969.

31. Aldieri, L.; Vinci, C.P. The Role of technology spillovers in the process of water pollution abatement for large international firms. Sustainability 2017, 9, 868. [CrossRef]

32. Awan, U.; Arnold, M.G.; Golgeci, I. Enhancing green product and process innovation: Towards an integrative framework of knowledge acquisition and environmental investment. Bus. Strat. Environ. 2020. [CrossRef]

33. Ebrahimi, B.; Dellnitz, A.; Kleine, A.; Tavana, M. A novel method for solving data envelopment analysis problems with weak ordinal data using robust measures. Expert Syst. Appl. 2021. [CrossRef]

34. Awan, U.; Nauman, S.; Sroufe, R. Exploring the effect of buyer engagement on green product innovation: Empirical evidence from manufacturers. Bus. Strat. Environ. 2021, 30, 463-477. [CrossRef]

35. Lin, Y.; Yan, L.; Wang, Y.M. Performance evaluation and investment Analysis for container port sustainable development in China: An inverse DEA approach. Sustainability 2019, 11, 4617. [CrossRef]

36. Färe, R.; Knox Lovell, C.A. Measuring the technical efficiency of production. J. Econ. Theory 1978, 19, 150-162. [CrossRef]

37. Aldieri, L.; Vinci, C.P. Innovation effects on employment in high-tech and low-tech industries: Evidence from large international firms within the triad. Eurasian Bus. Rev. 2018, 8, 229-243. [CrossRef]

38. Lazear, E. Balanced skills and entrepreneurship. Am. Econ. Rev. 2004, 94, 208-211. [CrossRef]

39. Cohen, W.M.; Levinthal, D.A. Absorptive capacity: A new perspective on learning and innovation. Admin. Sci. Quart. 1990, 35, 128-152. [CrossRef]

40. Lettl, C.; Rost, K.; von Wartburg, I. Why are some independent inventors "heroes" and others "hobbyists"? The moderating role of technological diversity and specialization. Res. Policy 2009, 38, 243-254. [CrossRef]

41. Noailly, J.; Shestalova, V. Knowledge spillovers from renewable energy technologies-Lessons from patent citations. Environ. Innov. Soc. Transit. 2017, 22, 1-14. [CrossRef]

42. Nemet, G.F. Inter-Technology knowledge spillovers for energy technologies. Energy Econ. 2012, 34, 1259-1270. [CrossRef]

43. Nemet, G.F.; Johnson, E. Do important inventions benefit from knowledge originating in other technological domains? Res. Policy 2012, 41, 190-200. [CrossRef]

44. Grafström, J.; Lindman, Å. Invention, innovation and diffusion in the European wind power sector. Technol. Forecast. Soc. Chang. 2017, 114, 179-191. [CrossRef]

45. Grafström, J. International knowledge spillovers in the wind power industry: Evidence from the European Union. Econ. Innov. New Technol. 2018, 27, 205-224. [CrossRef]

46. Marin, G.; Mazzanti, M. The evolution of environmental and labor productivity dynamics. J. Evol. Econ. 2013, 23, 357-399. [CrossRef] 
47. Cecere, G.; Mazzanti, M. Green jobs and eco-innovations in European SMEs. Res. Energy Econ. 2017, 49, 86-98. [CrossRef]

48. Dosi, G.; Freeman, C.; Nelson, R.; Silverberg, G.; Soete, L. Technical Change and Economic Theory; Pinter: London, UK, 1988.

49. Corradini, M.; Costantini, V.; Mancinelli, S.; Mazzanti, M. Unveiling the dynamic relation between R\&D and emission abatement: National and sectoral innovation perspectives from the EU. Ecol. Econ. 2014, 102, 48-59.

50. Aldieri, L.; Cincera, M. Geographic and technological R\&D spillovers within the triad: Micro evidence from US patents. J. Technol. Tansfer 2009, 34, 196-211.

51. Loury, G.C. Market structure and innovation. Q. J. Econ. 1979, 93, 395-410. [CrossRef]

52. Dasgupta, P.; Stiglitz, J. Uncertainty, industrial structure, and the speed of R\&D. Bell J. Econ. 1980, 11, 81-128.

53. Lucas, R.E., Jr. On the mechanics of economic development. J. Monet. Econ. 1988, 22, 3-42. [CrossRef]

54. Kelly, M.; Hageman, A. Marshallian externalities in innovation. J. Econ. Growth 1999, 4, 39-54. [CrossRef]

55. Griliches, Z. Issues in assessing the contribution of R\&D to productivity growth. Bell J. Econ. 1979, 10, 92-116.

56. Romer, P.M. Endogenous technological change. J. Political Econ. 1990, 98, 71-102. [CrossRef]

57. Grossman, G.M.; Helpman, E. Innovation and Growth in the Global Economy; MIT Press: Cambridge, MA, USA, 1991.

58. Jaffe, A.B.; Trajtenberg, M.; Henderson, R. Geographic localization of knowledge spillovers as evidenced by patent citations. Q. J. Econ. 1993, 108, 577-598. [CrossRef]

59. Van den Bergh, J.C.; Jeroen, C.J.M. Optimal diversity: Increasing returns versus recombinant innovation. J. Econ. Behav. Organ. 2008, 68, 565-580. [CrossRef]

60. Schoenmakers, W.; Duysters, G. The technological origins of radical inventions. Res. Policy 2010, 39, 1051-1059. [CrossRef]

61. Aldieri, L.; Vinci, C.P. Green economy and sustainable development: The economic impact of innovation on employment. Sustainability 2018, 10, 3541. [CrossRef]

62. Lundberg, E. Produktivitet och Räntabilitet; PA Norstedt and Soner: Stockholm, Sweden, 1961.

63. Jevons, W.S. Of the economy of fuel. In The Coal Question; Macmillan: London, UK, 1865.

64. Neary, J.P. On the short-run effects of technological progress. Oxford Econ. Pap. 1981, 33, 224-233. [CrossRef]

65. Hall, P.H.; Heffernan, S.A. More on the employment effects of innovation. J. Dev. Econ. 1985, 17, 151-162. [CrossRef]

66. Harrison, R.; Jaumandreu, J.; Mairesse, J.; Peters, B. Does innovation stimulate employment? A firm-level analysis using comparable micro-data from four European countries. Int. J. Ind. Organ. 2014, 35, 29-43. [CrossRef]

67. Llera, E.; Scarpellini, S.; Aranda, A.; Zabalza, I. Forecasting job creation from renewable energy deployment through a value-chain approach. Renew. Sustain. Energy Rev. 2013, 21, 262-271. [CrossRef]

68. Van der Zwaan, B.; Cameron, L.; Kober, T. Potential for renewable energy jobs in the Middle East. Energy Policy 2013, 60, $296-304$. [CrossRef]

69. Kattumuri, R.; Kruse, T. Renewable technologies in Karnataka, India: Jobs potential and co-benefits. Clim. Dev. 2019, 11, 124-137. [CrossRef]

70. Frondel, M.; Ritter, N.; Schmidt, C.M.; Vance, C. Economic impacts from the promotion of renewable energy technologies: The German experience. Energy Policy 2010, 38, 4048-4056. [CrossRef]

71. Almutairi, K.; Thoma, G.; Durand-Morat, A. Ex-Ante analysis of economic, social and environmental impacts of large-scale renewable and nuclear energy targets for global electricity generation by 2030. Sustainability 2018, 10, 2844. [CrossRef]

72. Wei, M.; Patadia, S.; Kammen, D.M. Putting renewables and energy efficiency to work: How many jobs can the clean energy industry generate in the US? Energy Policy 2010, 38, 919-931. [CrossRef]

73. Blanco, M.I.; Rodrigues, G. Direct employment in the wind energy sector: An EU study. Energy Policy 2009, 37, $2847-2857$. [CrossRef]

74. Okkonen, L.; Lehtonen, O. Socio-economic impacts of community wind power projects in Northern Scotland. Renew. Energy 2016, 85, 826-833. [CrossRef]

75. Comings, T.; Fields, S.; Takashi, K.; Keith, G. Employment Effects of Clean Energy Investments in Montana; Synapse Energy Economics Inc.: Cambridge, MA, USA, 2014.

76. Hondo, H.; Moriizumi, Y. Employment creation potential of renewable power generation technologies: A life cycle approach. Renew. Sustain. Energy Rev. 2017, 79, 128-136. [CrossRef]

77. Kahouli, S.; Martin, J.C. Can offshore wind energy be a lever for job creation in France? Some insights from a local case study. Environ. Model. Assess. 2018, 23, 203-227. [CrossRef]

78. Ejdemo, T.; Söderholm, P. Wind power, regional development and benefit-sharing: The case of Northern Sweden. Renew. Sustain. Energy Rev. 2015, 47, 476-485. [CrossRef]

79. Dvořák, P.; Martinát, S.; Van der Horst, D.; Frantál, B.; Turečková, K. Renewable energy investment and job creation; a crosssectoral assessment for the Czech Republic with reference to EU benchmarks. Renew. Sustain. Energy Rev. 2017, 69, 360-368. [CrossRef]

80. Tourkolias, C.; Mirasgedis, S. Quantification and monetization of employment benefits associated with renewable energy technologies in Greece. Renew. Sustain. Energy Rev. 2011, 15, 2876-2886. [CrossRef]

81. Moreno, B.; Lopez, A.J. The effect of renewable energy on employment. The case of Asturias (Spain). Renew. Sustain. Energy Rev. 2008, 12, 732-751. [CrossRef]

82. Jaffe, A.B. Technological opportunity and spillovers of R\&D: Evidence from firms' patents, profits and market value. Am. Econ. Rev. 1986, 76, 984-1001. [CrossRef] 
83. Aldieri, L.; Kotsemir, M.N.; Vinci, C.P. The role of environmental innovation through the technological proximity in the implementation of the sustainable development. Bus. Strat. Environ. 2019. [CrossRef]

84. Coelli, T.J.; Prasada Rao, D.S.; Battese, G.E. An Introduction to Efficiency and Productivity Analysis; Springer: New York, NY, USA, 2005.

85. Tobin, J. Estimation of relationship for limited dependent variables. Econometrica 1958, 26, 24-36. [CrossRef]

86. Simeonovski, K.; Kaftandzieva, T.; Brock, G. Energy efficiency management across EU countries: A DEA approach. Energies 2021, 14, 2619. [CrossRef]

87. Xu, T.; You, J.; Li, H.; Shao, L. Energy Efficiency Evaluation Based on Data Envelopment Analysis: A Literature Review. Energies 2020, 13, 3548. [CrossRef]

88. Mardani, A.; Streimikiene, D.; Balezentis, T.; Saman, M.; Nor, K.; Khoshnava, S. Data envelopment Analysis in energy and environmental economics: An Overview of the state-of-the-art and recent development trends. Energies 2018, 11, 2002. [CrossRef]

89. Wang, L.W.; Le, K.D.; Nguyen, T.D. Assessment of the energy efficiency improvement of Twenty-Five Countries: A DEA Approach. Energies 2019, 12, 1535. [CrossRef]

90. Fidanoski, F.; Simeonovski, K.; Cvetkoska, V. Energy efficiency in OECD countries: A DEA Approach. Energies 2021, 14, 1185. [CrossRef]

91. Ji, Y.; Lee, C. Data envelopment analysis. Stata J. 2010, 10, 267-280. [CrossRef]

92. Pastor, J.T.; Asmild, M.; Knox Lovell, C.A. The biennial Malmquist productivity change index. Socio. Econ. Plan. Sci. 2011, 45, 10-15. [CrossRef]

93. OECD, REGPAT Database. January 2018. Available online: https://www.oecd.org/sti/inno/intellectual-property-statistics-andanalysis.htm (accessed on 10 June 2018).

94. Bound, J.; Cummins, C.; Griliches, Z.; Hall, B.H.; Jaffe, A.B. Who Does RE D and Who Patents; National Bureau of Economic Research: Cambridge, MA, USA, 1982; Working Report No. w0908.

95. Pakes, A.; Griliches, Z. Patents and R\&D at the firm level: A first look. In RED, Patents, and Productivity; Zvi, G., Ed.; University of Chicago Press: Chicago, IL, USA, 1984.

96. Bruns, S.B.; Kalthaus, M. Flexibility in the selection of patent counts: Implications for $p$-hacking and evidence-based policymaking. Res. Policy 2020, 49, 103877. [CrossRef]

97. Johnstone, N.; Managi, S.; Rodríguez, M.C.; Haščič, I.; Fujii, H.; Souchier, M. Environmental policy design, innovation and efficiency gains in electricity generation. Energy Econ. 2017, 63, 106-115. [CrossRef]

98. Jungmittag, A.; Welfens, P.J.J. Telecommunications, innovations and the long-term production function: Theoretical aspects and a cointegration analysis for West Germany 1960-1990. In The New Economy and economic growth in Europe and the US; Audretsch, D., Welfens, P.J.J., Eds.; Springer: Berlin, Germany, 2002; pp. 99-127.

99. Marin, G.; Lotti, F. Productivity effects of eco-innovations using data on eco-patents. Ind. Corp. Chang. 2016, 26, 1-24. [CrossRef]

100. Archibugi, D.; Coco, A. Is Europe becoming the most dynamic knowledge economy in the world? J. Common Mark. Stud. 2005, 43, 433-459. [CrossRef]

101. Jungmittag, A. Innovation dynamics in the EU: Convergence or divergence? A cross-country panel data analysis. Empirical Econ. 2006, 31, 313-331. [CrossRef]

102. European Commission. The 2000-2017 EU Industrial RED Investment Scoreboard; JRC Scientific and Technical Research Series; Joint Research Center-Institute for Prospective Technological Studies, Office for Official Publications of the European Communities: Luxembourg, 2018.

103. Bogliacino, F. Innovation and employment: A firm level analysis with European R\&D Scoreboard data. Economia 2014, 15, 141-154.

104. Hall, B.H.; Mairesse, J. Exploring the relationship between R\&D and productivity in French manufacturing firms. J. Econom. 1995, 65, 263-294.

105. Kravtsova, V. Foreign presence and efficiency in transition economies. J. Prod. Anal. 2008, 29, 91-102. [CrossRef]

106. Perman, R.; Ma, Y.; Common, M.; Maddisomn, D.; McGilvray, J. Natural Resource and Environmental Economics; Pearson: Edinburgh, UK, 2011.

107. Hoff, A. Second stage DEA: Comparison of approaches for modelling the DEA score. Eur. J. Oper. Res. 2007, 181, 425-435. [CrossRef]

108. Bartik, T.J. The social value of job loss and its effect on the costs of US environmental regulations. Rev. Environ. Econ. Policy 2015, 9, 179-197. [CrossRef]

109. Battke, B.; Schmidt, T.S.; Stollenwerk, S.; Hoffmann, V.H. Internal or external spillovers—Which kind of knowledge is more likely to flow within or across technologies. Res. Policy 1996, 45, 27-41. [CrossRef]

110. Mariyakhan, K.; Mohamued, E.A.; Asif Khan, M.; Popp, J.; Olàh, J. Does the level of absorptive capacity matter for carbon intensity? Evidence from the USA and China. Energies 2020, 13, 407. [CrossRef]

111. Hao, Y.; Huang, Z.; Wu, H. Do carbon emissions and economic growth decouple in China? An empirical analysis based on provincial panel data. Energies 2019, 12, 2411. [CrossRef]

112. Son, D.; Kim, J.; Jeong, B. Optimal operational strategy for power producers in Korea considering renewable portfolio Standards and emissions trading schemes. Energies 2019, 12, 1667. [CrossRef] 
113. Vasylieva, T.; Lyulyov, O.; Bilan, Y.; Streimikiene, D. Sustainable economic development and greenhouse gas emissions: The dynamic impact of renewable energy consumption, GDP and corruption. Energies 2019, 12, 3289. [CrossRef]

114. Haseeb, M.; Kot, S.; Hussain, H.I.; Jermsittiparsert, K. Impact of economic growth, environmental pollution and energy consumption on health expenditure and R\&D expenditure of ASEAN countries. Energies 2019, 12, 3598.

115. Costantini, V.; Crespi, F. Environmental regulation and the export dynamics of energy technologies. Ecol. Econ. 2008, 66, 447-460. [CrossRef]

116. Böhringer, C.; Rosendahl, K.E. Greening electricity more than necessary: On the cost implications of overlapping regulation in EU climate policy. Schmollers Jahrbuch 2011, 131, 469-492. [CrossRef]

117. Böhringer, C.; Keller, A.; van der Werf, E. Are green hopes too rosy? Employment and welfare impacts of renewable energy promotion. Energy Econ. 2013, 36, 277-285. [CrossRef]

118. Lehr, U.; Nitsch, J.; Kratzat, M.; Lutz, C.; Edler, D. Renewable energy and employment in Germany. Energy Policy 2008, 36, 108-117. [CrossRef]

119. Garcia, A.; Jaumandreu, J.; Rodriguez, C. Innovation and Jobs: Evidence from Manufacturing Firms; MPRA: Munich, Germany, 2004; Working Paper No. 1204. 